\title{
ANTECEDENTS TO EXPORT PERFORMANCE AND HOW ITALIAN AND SLOVENIAN SMES INNOVATE DURING TIMES OF CRISIS
}

\author{
Maurizio Massaro \\ Udine University, Udine, Italy \\ Arthur Rubens \\ Florida Gulf Coast University, Fort Myers, FL \\ Roland Bardy \\ Florida Gulf Coast University, Fort Myers, FL \\ Carlo Bagnoli \\ Ca' Foscari University of Venice, Venice, Italy
}

\begin{abstract}
This paper explores how small and medium enterprises (SMEs) operating in Northern Italy and Slovenia used their innovative potential to expand business across the border while their home markets suffered from the great recession that started in 2007. The background of the study is an analysis of the antecedents to export performance and internationalization, which specifically asked whether innovating incrementally or innovating radically contributes to export performance in foreign markets and how this ultimately interacts with strategic considerations and the propensity to take risks, during times of economic risks. The findings of the study showed that export performance is positively influenced by incremental innovation and risk preference, and that there is a relationship between innovation and export performance. These findings contribute to the question whether classical internationalization theories such as the Uppsala Internationalization Model and the Innovation-related Model, can be applied in contingency situations of economic crisis.
\end{abstract}

Keywords: SME, internationalization strategies and theories, Entering foreign markets, Radical and incremental innovation, Risk preference, Export performance, Strategic intent.

DOI: http://dx.doi.org/10.15549/jeecar.v4i1.153

\section{INTRODUCTION}

There is a great sense of unease in the world today. In the past year, we have seen dramatic changes politically, economically, and socially throughout the U.S. and Europe which ultimately affects the entire world. These changes range from the passage of Brexit in the U.K., to the election of Donald Trump in the 
U.S., to the rise of nationalistic parties throughout Europe. The often-cited events that have led to these changes are globalization and its effect on workers in the west, and the rise of refugees migrating to the western nations from conflict-ridden regions in the world.

If we reflect back, much of this underlying unease started with the deep economic recession in 2007 and its subsequent impact on our world markets. During the great recession, many countries saw tremendous job losses. However, in spite of dramatic increases in the stock market worldwide, the recovery from the great recession has been very slow. In addition, many countries still see continued high unemployment among various groups. This has resulted in a growing sense of despair among businesses and world leaders with a realization that this economic crisis, or ones like is, will probably continue (Elliott, 2011; Financial Forecast Center, 2015; Eurostat, 2015) in the future. Although these uncertainties exist, politicians, business practitioners and academic scholars in countries throughout the world, continue to explore ways to stimulate their economy and develop practices that can create entrepreneurial opportunities, and promote innovation in which their economy can grow in our worldwide marketplace.

This urgency to find solutions is greatest in countries where internal demand for goods and services has been greatly reduced due to the global financial crisis and slow recovery. With small to medium size enterprises (SMEs) composing the largest sector of business activities, many of these firms look at internationalization and export opportunities as the best way to survive in depressed markets and fight their way out of their current predicament of a slow, lingering recovery. Research has shown that a myriad of external events forces SMEs to assume a more entrepreneurial posture of innovativeness and risk-taking in order to remain competitive in their home markets (DeClercq et al., 2015; Kraus et al., 2012; Harms et al., 2010; Covin and Slevin, 1991). Therefore, one of the primary objectives of our study is to better understand and determine the differing attitudes and motivations that are given by SMEs to explore business opportunities in neighboring regions across the border.

The area and group that we are studying is SMEs in Northern Italy and Slovenia - two areas that have been greatly affected by the economic recession of 2007-2010. The authors feel that by studying the drivers of SME's internationalization during times of crisis, it will provide insight to the multiple factors that fosters the decision of SME managers to confront the challenges of entering a foreign market. In addition, our study will assess whether some of the classical internationalization strategy theories explain the patterns of internationalization observed in cross-border business between Italy and Slovenia, in order to determine if classical internationalization theories can be applied in contingency situations of economic crisis.

Specifically, our analysis explores whether firms in our studied region innovated incrementally or innovated radically, as well as what other factors influenced an SME's intention to grow and to take risks in a cross border environment. In pursuit of this, we conducted a survey of SMEs in Northern Italy and Slovenia, based on a specifically devised questionnaire. This questionnaire is linked to several research questions which we developed when examining both the literature on export performance antecedents and traditional internationalization theories. We believe by focusing on the role which innovation and risk preference play for businesses to expand internationally, and on how traditional internationalization theories can adequately apply internationalization patterns of SMEs in times of crises, we will ultimately be able to understand the gap between classical theory and SMEs export decisions in contingencies such as an economic downturn. However, in doing this, we are aware that empirical research in international business (IB) is difficult at best, and that in IB research the researchers seldom have the luxury of randomized controlled experiments. Yet, even the best theories are subject to innumerable externalities that impact market condition and endogeneity problems that are inherently part of IB research (Reeb, Sakakibara, \& Mahmood, 2012).

Our paper is organized as follows. The first section of our paper reviews the literature by presenting the antecedents of cross-border venturing: export performance, strategic intent and risk performance, and the accompanying hypothesis for our research, as well as providing a short review of the relevant International Business (IB) theories. The second section of our paper describes the hypothesis 
development and the research context. Following this, the third section of our paper presents the study methodology describing the development of the survey instrument and the data analysis model. The fourth section of the paper presents the study results, and finally the paper concludes with a discussion of the implications of the study, as well as the limitations and directions for future research.

\section{ANTECEDENTS OF EXPORT PERFORMANCE}

The reasons why and when firms export, the ways and means they export, as well as the role that innovation plays and the method by which innovation is employed, are all subjects and topics that are open to discussion and research.

Over the last 20-25 years, internationalization of both large and small firms has been extensively researched and studied from a variety of viewpoints (organization theory, marketing, strategic management, international management, small business management, etc.) and issues; e.g., international decision-making, management, development of international activities, and factors favoring or disfavoring internationalization, etc. (Ruzzier, Hisrich, and Antončič, 2006). In the last decade, in particular, we have seen a number of studies on the internationalization of SMEs from various perspectives (Ruzzier, Antončič and Konečnik, 2006, Ruzzier, Hisrich and Antončič 2006, Masum and Fernandez 2008, Daszkiewicz and Wach 2012). In general, the main focus of this research has been on small-firm internationalization and issues relating to exports and the development of export sales (Leonidou and Katsikeas, 1996). We are also seeing various scholars and policy makers conducting research on the export performance of SMEs (European Commission, 2007; Moini and Moini, 1995; Wolff and Pett, 2000).

In these studies, and other sources, it is widely recognized that a number of drivers of export performance have intensified globalization such as declines in trade barriers, advances in telecommunications, informatics, and lower transportation costs to name a few (Charoensukmongkol, 2016). These drivers, combined with the fact that SMEs are acknowledged as vital to many countries' development and well-being (Cowling, Liu, Ledger, and Zhang, 2015; Reynolds, 1997), have opened the doors to international market opportunities for many SMEs worldwide.
In order to better understand the internationalization of SMEs, a growing number of studies will have used one or more theoretical frameworks which look extensively at the process and varied antecedents of the internationalization of SMEs. However, these theoretical frameworks do not always provide a clear understanding of the internationalization of SMEs. For example, although one of the primary resources available to SMEs when internationalizing would be innovation and entrepreneurial characteristics such as risk preference and strategic intent, previous empirical evidence appears to be conflicting on this subject. For example, in a study of businesses located in Great Britain, the authors of the study could not fully explain variations they found in several performance variables between an original survey and its follow up (Wright, Westhead and Ucbasaran, 2007). Their research did not reveal whether these businesses regarded exporting as a path to firm growth or if they just sporadically exploited opportunities that showed up. Hence, it could be posited that these opportunity-driven firms do not wish to engage in the risk of a long-term foreign commitment and thus follow an incremental internationalization path (Bell, Crick and Young, 2004). However, would these conclusions hold when the growth path of a firm is disrupted through market crises, and would this change risk propensity? Although, Cowling, Liu, Ledger, and Zhang (2015) in their study confirmed the impact that the financial downturn had on SMEs in the U.K. (4 in 10 experienced a fall in employment and 5 in 10 experienced a fall in sales), it also found that many of these SMEs' entrepreneurs (based on select characteristic) had a desire to grow; however, only select SMEs (larger SMEs with access to capital) could grow during market downturn.

Based on this research we can conclude that having a greater understanding of SMEs' risk preference and strategic intent and how these variables impact SMEs' export performance would be useful information for practitioners, policy makers and academics. Therefore, a better comprehension of the phenomenon with new practical insights will increase the theoretical debate on export performance and internationalization. In addition, these new findings might be useful for policy makers to better understand how to support internationalization process of SMEs during a 
period of financial and economic crisis.

\section{The role of innovation}

The Resource Based View (RBV) of the firm has been widely utilized in the exporting literature (see, e.g., Dhanaraj and Beamish, 2003). The RBV literature places emphasis on the firm's ability to accumulate and combine resources to acquire and foster competitive advantage (Danneels, 2002; Verona, 1999). Morgan et al (2004) found that the firm's ability to enter foreign markets is positively associated with tangible and intangible knowledge based resources. Within this context, innovation capability has been shown to provide a unique competitive advantage in helping firms to improve their products and processes to successfully operate in global markets (Yi et al., 2013, p. 394). In support of this, Nguyen et al. (2008) reported that innovative firms are more likely to export and showed a link with R\&D expenses and export performance of Danish manufacturing firms. Harris and Li (2009) in research on the relation between $R \& D$ and export for the UK., found that R\&D activities play an important role for firms to overcome barriers to internationalization. Basile (2001) in support of the relationship between innovation and internationalization, found that the exports for innovating firms are higher than for noninnovating firms. Similar results are reported by Pla-Barber and Alegre (2007) for the French biotechnology industry.

Although the literature is plentiful with the connection between innovation and internationalization, there is not a unanimous consensus. For example, Wakelin (1998) found that UK innovators are less likely to become exporters than non-innovators of the same size. Lefebvre et al. (1998) also reported that the association between innovation and exports is insignificant. In addition, Anon-Higon and Driffield (2011) did not find robust evidence that process innovation increases the probability to export beyond product innovation. Results are even more contradictory in Deng et al. (2014) who found a negative correlation between innovation and survival of exporters. Interestingly, while there is ample empirical evidence of the linkage between a country's export performance and its innovation activities at a macro level, less attention has been paid within the micro level in general and especially with SMEs (Love et al.,
2009; Nguyen et al., 2008).

A very limited number of studies have analyzed the impact of the different kinds of innovation on export performance with most of them using a broad definition of innovation (e.g. O'Cass and Weerawardena, 2009). Although, Nguyen et al (2008) investigated how firms' export behavior depends on innovation activities distinguishing between product innovation and process innovation, less attention has been paid on the difference between radical and incremental innovations. Depending on the degree of novelty from the firm's point of view, the literature differentiates incremental innovations (II) and radical innovation (RI). Incremental innovations normally refer to improvements made to the company's existing products, while radical innovation refers to improvements to the product that are totally new to the company (Minguela-Rata et al., 2014). Generally, radical innovations present more market risk and uncertainty and are harder to come by even though they have a much larger effect on firms' performance potentially.

During the 2007-2010 economic crisis, the difficulties in obtaining financing affected investment opportunities, especially for SMEs. In order to better understand how different kinds of innovation affect export performance during financial crisis we draw our first three research questions:

- RQ1: How does RI affect export performance in SMEs during the financial crisis?

- RQ2: How does II affect export performance in SMEs during the financial crisis?

- RQ3: Is there any relationship between RI and II during the financial crisis?

The role of strategic intention and risk preference

Innovation and export are the results of firms' 'knowledge resources' (Nonaka and Takeuchi, 1995). These 'knowledge resources' create the necessary potential for supporting innovation on one side and create the basis to stimulate export performance on the other side. However, the knowledge resources must be followed by some form of strategic decisionmaking that reflects the desirability of pursuing current opportunities (Grant, 1996). Thus, a risk-taking attitude and strategic intent orientation to the firm's growth are both central elements to support innovation, as well as 
internationalization of SMEs. However, interestingly, to the best of the author's knowledge, a cognitive perspective analyzing the role of these variables has rarely been used in studies on SMEs' export performance.

Hamel and Prahalad (1989) defined strategic intent(SI) as what motivates firms to create and to sustain a consistent ambition to overcome resource constraints for implementing a desired strategy: "Whereas the traditional view of strategy focuses on the degree of fit between existing resources and current opportunities, strategic intent creates an extreme misfit between resources and ambitions" (Hamel and Prahalad, 1989, p. 67). Hence, SMEs entrepreneurs are usually inextricably linked to the decision-making process within the organization (Henry, 2013, p. 85) and thus, the deliberate choice of seeking out new opportunities could be problematic.

Hutchinson, Fleck, and Lloyd-Reason (2009), found that fear of losing control, together with lack of knowledge about external environment, among others, are deemed to be external barriers to internationalization. Other studies have reported that in SMEs, SI is more focused on maintaining independence rather than gathering new growth opportunities (Cassar, 2007; Choi and Shepherd, 2004; Douglas, 2013; Døving and Gooderham, 2008; Dutta and Thornhill, 2008). Consequently, this divergent approach could affect export performance since firms which value long-term survival and independence will measure performance through firm longevity, while firms with a market-domination objective will be more preoccupied with growth measures (St-Pierre and Audet, 2011).

Based on this premise, we derive our next three research questions.

- RQ4: How does SI affect export performance in SMEs during the financial crisis?

- RQ5: How does SI affect Radical Innovation in SMEs during the financial crisis?

- RQ6: How does SI affect Incremental Innovation in SMEs during the financial crisis?

According to Acedo and Galan (2011), entrepreneurs have a greater tolerance of uncertainty. From this line of research, the literature has developed the concept of risk preference (RP), which consists of a general tendency or the general desire to pursue or avoid risks (Barbosa et al., 2007, p. 89). Based on this approach entrepreneurs will show different risk- propensities; e.g., individuals with higher preference for risk will exhibit a higher level of entrepreneurial intention. Considering that internationalization is riskier than national activities because firms are frequently forced to deal with unknown environments, culture, and markets, it could easily be surmised that RP affects export performance. However, there is another effect. According to Cohen et. al. (2014, p. 298), economic cycle, especially during a period of recession, affects SMEs' investments due to resource constraints and the higher uncertainty of returns. Therefore, firms' RP could potentially affect innovation investments which consequently would affect SMEs' export performance (Cohen et al., 2014, p. 297).

Based on this line of thought, we draw our sixth, seventh and eighth research questions:

- RQ7: How does RP affect export performance in SMEs during the financial crisis?

- RQ8: How does RP affect Radical Innovation in SMEs during the financial crisis?

- RQ9: How does RP affect Incremental innovation in SMEs during the financial crisis?

\section{International Business (IB) theories}

In studying models for SME internationalization, three different perspectives or approaches are most prominent: (a) the market perspective which focuses on studies of internationalization or diversification strategies; (b) the entrepreneurship perspective, which looks to new venture development and entrepreneurial activities; and (c) the firm perspective, with its roots in a defined stage model of internalization (Ahokangas, 1998). Although all three perspectives are looked at in SME research, much of the literature comes out of the stage approach of the firm perspective. The two primary stage models that have been developed are: the Uppsala Internationalization Model (Umodel) and the Innovation-related Model (Imodel) for expounding on the process of internationalization,

In the U-Model (Johanson and Vahlne, 1975, 1992), the concept of foreign market commitment is composed of two factors: the amount of resources committed and the degree of commitment. The former can be operationalized as the size of the investments 
needed, e.g. in terms of marketing, organization and human resources, while the latter refers to the difficulty of identifying an alternative use for the resources and transferring them to that alternative use. This approach proposes four stages: 1) No regular export activity; 2) Export via independent representatives; 3) Establishing an overseas sales subsidiary; and 4) Establishing overseas production/ manufacturing units (Andersen, 1993).

In the I-model (Cavusgil, 1980), internationalization is a firm's innovation strategy in which the different stages are linked to different exporting trends and dynamics. Five stages of international commitment are proposed: 1) Pre-involvement; 2) Reactive/Opportunistic; 3) Experimental; 4) Active; 5) Committed involvement. Even though these two approaches are different in their theoretical bases, from an empirical point of view, both approaches reach similar conclusions with each proposing a development path to explain export performance (Iacobucci and Spigarelli, 2013).

However, both the ' $U$ ' and the 'I' models have been recently questioned. The developing model is time dependent and assumes a predetermined path of development which makes it unsuitable for firms with extensive international experience and firms in hightechnology, knowledge intensive or service sectors (Bell, 1995; Ibeh et al., 2004). In addition, some SMEs in these sectors 'leapfrog' the predetermined stages because they either focus on global market niches or on decreases in transportation and communication costs (McDougall and Oviatt 1996; Belso-Martines 2006). Also, there are firms that are "born global": new firms that from their onset are designed and modeled to export to foreign markets.

The slow recovery of the global financial and economic crisis has forced local firms (especially SMEs operating in countries where the crisis has strongly reduced internal demand) to develop an accelerated path to internationalization through increasing their exports. Subsequently, these firms are forced to compensate for the internal market reduction with an external source of sales to survive. Interestingly, there is limited research on that phenomenon which could be characterized as a "contingency approach" to overcome adversities in the home market. It is the authors' contention that a contingency approach to internationalization should be developed to cover those situations of firms that operate in markets that were impacted by externality such as a financial and economic crisis.

In our review of the literature, we found only a few similar approaches towards new models of internationalization. One of these approaches is the theoretical integrative conceptual model of international entrepreneurship proposed by Ruzzier, Hisrich and Antončič (2006). This approach is based on four internationalization properties (mode, market, product, and time), internationalization performance, and key antecedents and consequences of the internationalization process; however, within this approach, contingency situations were not examined.

Contingency situations such as the 2007-2010 crisis have a direct impact on the antecedents of internationalization for an SME. For example, it goes without saying that situations such as reduced money availability and increased uncertainty almost certainly affect innovation plans of SMEs. At the same time, higher competitive pressure due to the reduction of internal markets boost export propensity and the use of innovative advancements. In the literature, that links innovation to export performance (Basile, 2001; Cassiman and Golovko, 2011; O'Cass and Weerawardena, 2009), there is evidence that the intensity and direction of this link of innovation to export performance is context-specific. While Yi et al. (2013) found that innovation supports export performance, Deng et al. (2014) found a negative correlation between innovation and survival of exporters.

The contrast between these studies support the need to develop more of a contingency approach that could be used to better understand firm's evolution during a period of financial and economic crisis. In addition, from a policy perspective, understanding the impact of variables that affect SMEs' export performance in a period of crisis would be useful to develop strategies which stimulate SMEs' intentions to expand across borders.

\section{HYPOTHESIS DEVELOPMENT AND RESEARCH CONTEXT}

One of the desired outcomes of our research is to identify a connection between strategic intent, risk perception, innovation (both radical 
and incremental) and export performance. To analyze the relationships with these variables we draw a series of hypotheses for each research question developed in the previous sections. More precisely, for each research question two hypotheses are developed: HO (null hypothesis), that generally assumes the existence of no influence between variables analyzed and HA an opposing hypothesis of the null hypothesis. Table I below summarizes each hypothesis developed and Figure 1 shows our research model.

Table 1. Research questions and hypotheses

\begin{tabular}{|c|c|c|}
\hline \multirow{3}{*}{$\begin{array}{l}\quad \text { Research questions } \\
\text { RQ1. } \\
\text { How does RI affect export } \\
\text { performance in SMEs during financial } \\
\text { crisis? }\end{array}$} & \multicolumn{2}{|r|}{ Research Hypothesis } \\
\hline & $\mathrm{H}_{0}$ & There is no influence of RI on Export performance \\
\hline & $\mathrm{H}_{\mathrm{A}}$ & $\begin{array}{l}\text { There is a direct influence of RI on Export } \\
\text { performance }\end{array}$ \\
\hline \multirow{2}{*}{$\begin{array}{l}\text { RQ2. } \\
\text { How does II affect export performance } \\
\text { in SMEs during financial crisis? }\end{array}$} & $\mathrm{H}_{0}$ & There is no influence of II on Export performance \\
\hline & $\mathrm{H}_{\mathrm{A}}$ & $\begin{array}{l}\text { There is a direct influence of II on Export } \\
\text { performance }\end{array}$ \\
\hline \multirow{2}{*}{$\begin{array}{l}\text { RQ3 } \\
\text { Is there any relationship between RI } \\
\text { and II?? }\end{array}$} & $\mathrm{H}_{0}$ & There is no relationship between RI and II \\
\hline & $\mathrm{H}_{\mathrm{A}}$ & There is a direct relationship between RI and II \\
\hline \multirow{2}{*}{$\begin{array}{l}\text { RQ4 } \\
\text { How does SI affect export performance } \\
\text { in SMES during financial crisis? }\end{array}$} & $\mathrm{H}_{0}$ & There is no influence of SI on Export Performance \\
\hline & $\mathrm{H}_{\mathrm{A}}$ & $\begin{array}{l}\text { There is a direct influence of SI on Export } \\
\text { Performance }\end{array}$ \\
\hline \multirow{2}{*}{$\begin{array}{l}\text { RQ5 } \\
\text { How does SI affect Radical Innovation } \\
\text { in SMEs during financial crisis? }\end{array}$} & $\mathrm{H}_{0}$ & There is no influence of SI on RI \\
\hline & $\mathrm{H}_{\mathrm{A}}$ & There is a direct influence of SI on RI \\
\hline \multirow{2}{*}{$\begin{array}{l}\text { RQ6 } \\
\text { How does SI affect Incremental } \\
\text { Innovation in SMEs during financial } \\
\text { crisis? }\end{array}$} & $\mathrm{H}_{0}$ & There is no influence of SI on II \\
\hline & $\mathrm{H}_{\mathrm{A}}$ & There is a direct influence of SI On II \\
\hline \multirow{2}{*}{$\begin{array}{l}\text { RQ7 } \\
\text { How does RP affect export } \\
\text { performance in SMEs during financial } \\
\text { crisis? }\end{array}$} & $\mathrm{H}_{0}$ & There is no influence of RP on Export Performance \\
\hline & $\mathrm{H}_{\mathrm{A}}$ & $\begin{array}{l}\text { There is a direct influence of of RP on Export } \\
\text { Performance }\end{array}$ \\
\hline \multirow{2}{*}{$\begin{array}{l}\text { RQ8 } \\
\text { How does RP affect Radical Innovation } \\
\text { in SMEs during financial crisis? }\end{array}$} & $\mathrm{H}_{0}$ & There is no influence of RP on RI \\
\hline & $\mathrm{H}_{\mathrm{A}}$ & There is a direct influence of RP on RI \\
\hline \multirow{2}{*}{$\begin{array}{l}\text { RQ9 } \\
\text { How does RP affect Incremental } \\
\text { Innovation in SMEs during financial } \\
\text { crisis? }\end{array}$} & $\mathrm{H}_{0}$ & There is no influence of RP on II \\
\hline & $\mathrm{H}_{\mathrm{A}}$ & There is a direct influence of RP on II \\
\hline
\end{tabular}

$\mathrm{RI}=$ Radical Innovation; and II=Incremental Innovation

In order to test our hypotheses, we approached SMEs operating in Northern Italy and Slovenia. Although Italy and Slovenia are countries with different levels of 
internationalization, both of them are highly represented by small, family owned businesses. Northern Italy, in particular, is quite unique since it has a large number of family run SMEs, with many located in designated Industrial Districts, which are unique to Italy's economic development.

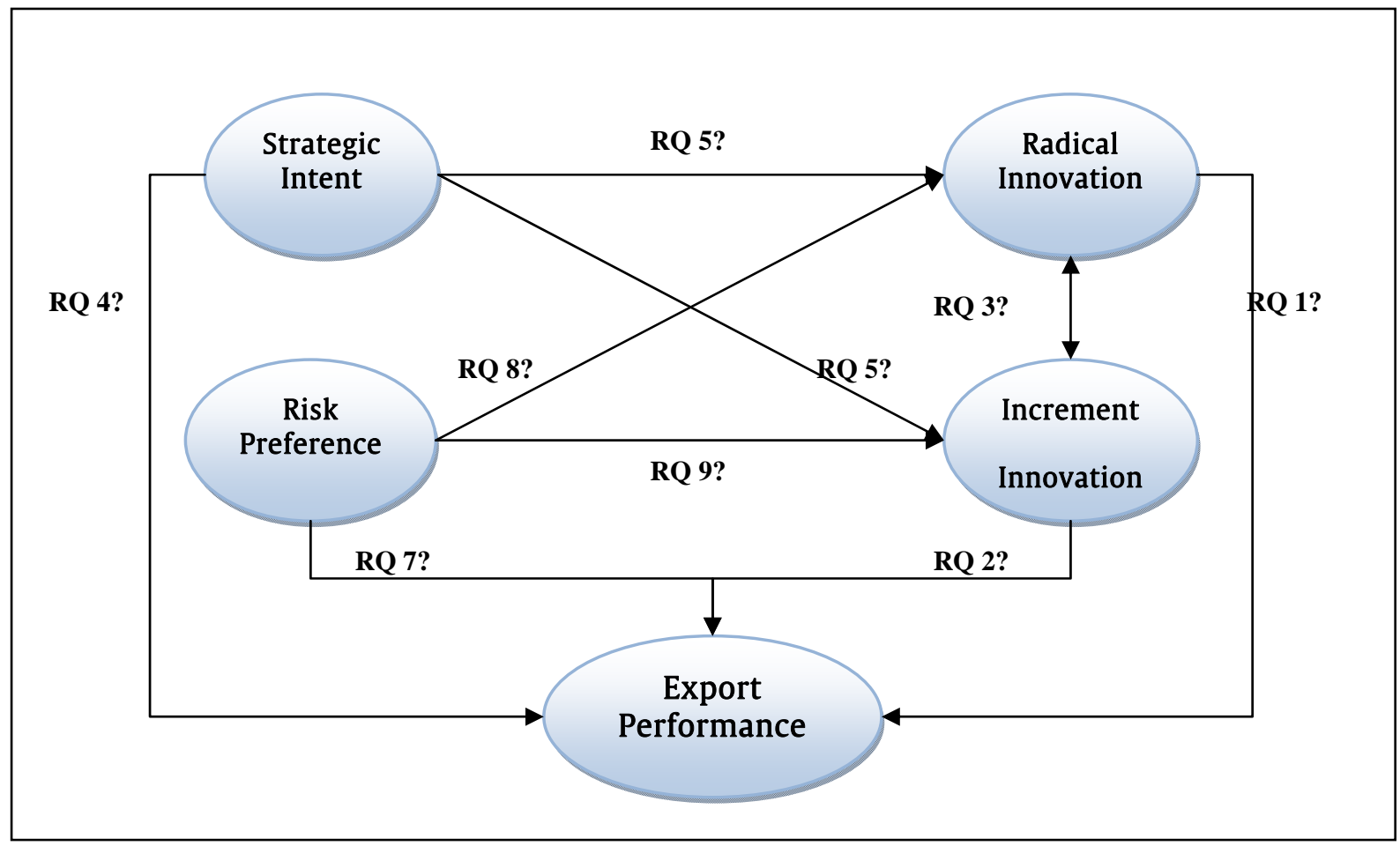

Figure 1 - Research model

Briefly, Italy's Industrial districts (ID) have been a fundamental part of Italy's economic communities for SMEs since the 1970s. These districts and other forms of territorial clusters are the backbone for SME- entrepreneurship, family business, and close collaboration within and between industries. This collaboration has positioned Italy as a leading exporter and innovator. Italy's IDs have demonstrated how small SMEs could not only operate successfully but also compete on the world stage. A number of these IDs are located in the Northern areas of Italy. For example, the province of FriuliVenezia Giulia, which directly borders Slovenia, is one of the top twenty European innovative regions in relation to innovative activity and labor productivity (Paci and Usai, 2000).

Although Slovenia is an emerging economy and is relatively a new member of the EU (May 1 , 2004), they have engaged in internationalization and export activities since the early 1950s (while they were part of the former Yugoslavia). In addition, over the last decade they have performed better in terms of outward FDI as a percentage of their GDP when compared to other Central and Eastern European countries (UNCTAD, 2004). Although they have performed well, when comparing Slovenia to Italy and other developed European nations, Slovenia significantly lags as an international exporter (Svetlicic, 2007). In 2014, in terms of the relative size of exports, Slovenia ranked 11th among EU members, and exports of goods and services represented 76.5\% of GDP (Slovenia Times, 2015). Much of Slovenia trading has been with neighboring nations, and over the last few years there has been a slow but steady increase in their outward FDI (Slovenia Times, 2015). Conversely, Italy is the 8th largest exporter in the world, exporting $\$ 509$ billion in 2014. Much of their exports (over 62\%) are traded in Europe (OEC, 2016).

In spite of the differences between the two countries, there are similarities: both Italy and Slovenia were hit hard by the worldwide financial crisis of 2008-2010 which severely strained both of their economies. This is particularly true in Slovenia, where, it suffered a sharp decrease of GDP per capita by $7.9 \%$ in 2009 (OECD 2009). 
Domestic demand continued to decline, and these declines have had the greatest impact on SMEs (European Commission, 2014). Because of their specific characteristics, SMEs in Northern Italy and Slovenia were able to recover rather quickly achieving a highly competitive status by 2015 (OEC, 2016). This can be demonstrated by the two graphs exhibited in Figure 2.

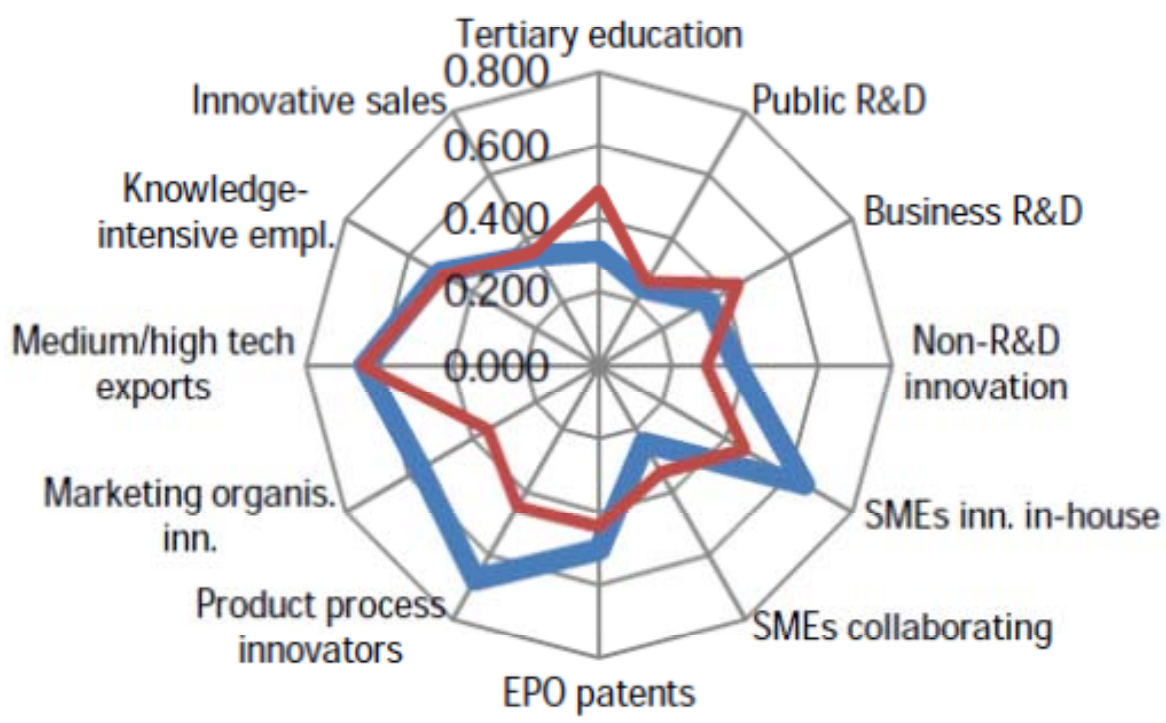

Zahodna Slovenija (SI02)

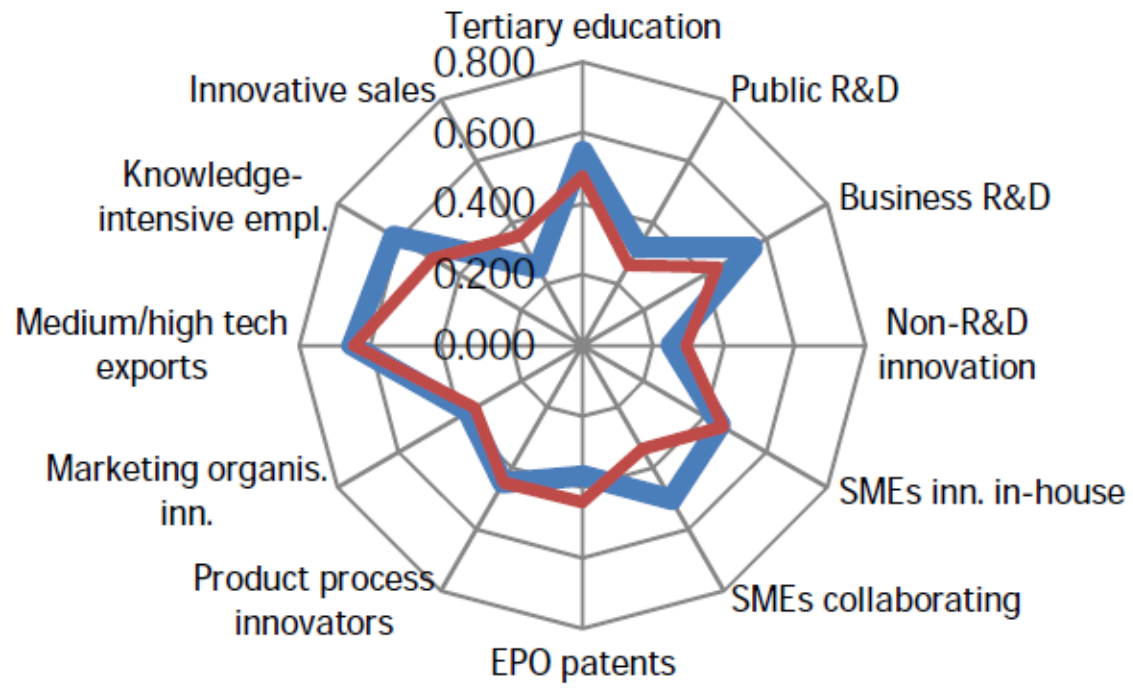

Figure 2: Relative Strengths of Friuli-Venezia Giulia and Zahodna Slovenjia vs. EU 28 Source: EU Regional Innovation Scoreboard 2016 (European Commission 2016)

The two graphs demonstrate that the businesses in the two districts have learned their lessons. Both score well when compared to the EU 28 average, with Friuli Venezia-Giulia leading in innovation and Zahodna Slovenija in SME collaboration and knowledge-intensive 
employment. It is the authors' contention that their innovative potential, their agility, and their risk aversion helped the SMEs of Friuli Venezia-Giulia and of Zahodna Slovenija to successfully master the challenges of the 20072010 crisis and to withstand increasing foreign and domestic competition.

The authors feel that having a better understanding of the drivers that these two regions employed to expand internationalization will bring new insights into the competitiveness of SMEs.

\section{METHODOLOGY}

Our study was a subset of a larger multicountry project that had been initiated after the economic downturn to measure "the strategic impact" of SMEs' activities within the Mediterranean region. In our study, we examined three performance drivers for crossborder venturing in our sample population of SMEs: 1) Innovation; 2) strategic intent; and 3) risk preference.

Procedurally, the study authors contacted local Italian and Slovenian Chambers of Commerce requesting a list of SMEs within their territories. For the purposes of our study we used the EU definition of an SME: an enterprise employing fewer than 250 people. However, many of the SMEs in Italy and Slovenia employ considerably less (generally less than 50). The SMEs in our sample have minimum revenue of $€ 0.5$ million with a maximum of $€ 48$ million.

The original list of SMEs provided by the local Chambers of Commerce was randomly selected, from which a total of 3,000 companies were obtained. Following the initial selection of the companies, an "email invite" was sent to the sample group asking the companies to participate in our study and to complete the study survey questionnaire. Following the initial email invite, two subsequent reminder emails were sent to the companies further encouraging them to complete the questionnaire and participate in our study. A total of 350 questionnaires or $9.57 \%$ of the total sample were returned to the research team.

\section{Survey instrument}

Innovation orientation (Radical Innovation versus Incremental Innovation)

To measure innovation attitude, we developed a list of 12 questions. We followed a self-assessment approached based on a scale of 1 to 5 , where respondents were asked to assess their opinion in the following areas: a) market innovation; b) product innovation; c) operational process innovation; d) customer management processes; e) product development processes; and f) social management processes. Following this, we used exploratory and confirmatory factor analysis to identify latent variables within the responses given. From this, analysis, we identified two main approaches to innovation: a) radical innovation approach and b) incremental innovation approach. Table 2 provides the complete list of questions developed and an explanation of the main results obtained.

\section{Risk Preference}

In regard to risk preference, we developed a list of 3 questions and asked respondents to evaluate these items on a 5 point Likert-scale. Questions were developed that had respondents comparing high risk projects with high possible returns to low risk-low return projects. We then asked respondents to evaluate market exploration approaches where respondents were comparing taking wideranging action, rather than gradually and incremental action. The final question focused on comparing brave actions rather than a waitand-see posture. Table 3 provides a list of these questions.

\section{Strategic Intent}

In order to assess strategic intent, we developed a set of 5 questions. Similar to the question format used in innovation orientation, we followed a self-assessment approach based on a 1 to 5 scale from least important to most important, where respondents were asked to evaluate the importance of firm's growth over firm's autonomy. The concept of growth against autonomy was drawn from Douglas' (2013) recognition of a twofold approach to entrepreneurship, where new ventures were either independence-oriented or growthoriented. In regard to control variables, we assumed that growth is accompanied by a proactive approach which shows that proactive, functionally diversified, and/or internationally oriented firms outperform the reactive, functionally concentrated, and local market oriented firms (Bagchi-Sen and Kuechler, 2000). 
In order to ascertain if growth is supported by proactive approaches, we added questions on the importance of the: product performance, novelty of the products, the material, and the immaterial quality of their products. Table 4 shows a complete list of the asked questions related to $\mathrm{SI}$.

\section{Export performance}

Several criteria are suggested in the literature and in practice to measure export performance. Gemunden (1991) noted that there are over 700 explanatory variables that have been advanced in the literature as determinants of export performance. Most researchers have restricted their analysis to a parsimonious model. The most commonly used indicators are sales profitability in comparison with domestic sales profitability (Nakos et al, 1998), regional scope of foreign sales (Reuber and Fisher, 1997) and return on sales (Elango, 2000, Shrader, 2001). It has also been suggested that, beyond objective financial measures of export performance, subjective measures of performance and profitability should also be used (Spanos and Lioukas, 2001). While managers' responses in survey research may be problematic due to the subjectivity of their perceptions, they often present the only alternative because frequently financial data for SMEs are unavailable or unreliable (Dess and Robinson, 1984). Thus, perceptual measures, such as used in this study, may provide more meaningful comparisons than "objective" data and "absolute" measures (Spanos and Lioukas, 2001).

To measure export performance, we asked respondents to compare their results to those of their competitors on a scale 1 to 5 . Specifically, we asked respondents to evaluate on a scale 1-5 their revenues from export, net profits derived from exports, and net operating profits, compared to their competitors.

\section{DATA ANALYSIS}

\section{Measurement model}

We used the structural equation modeling approach (SEM) to test our hypotheses. The use of structural equations allowed us to test factor structure, adjustment for measurement error, examination of relationships among predictor variables, and the simultaneous estimation of all parameters in the model (Andersen and Nielsen, 2009; Westland, 2012). According to
Dalilla (2000, p. 439), SEM's “strengths include simultaneous assessment of various types of relations among variable and the ability to rigorously examine and compare similarities among, and differences between, two or more groups of study participants." SEM has also been widely used as a research method in previous studies to analyze export performance (see Carneiro et al., 2011; Papadopoulos and Martín Martín, 2010; Robb et al., 2008; Shamsuddoha et al., 2009).

\section{Measurement validation}

Our research used a two-step measurement process. First, we developed some preliminary measures to decide which estimation model to use. Straub (1989, p. 150) has said: "researchers who utilize confirmatory research findings first need to demonstrate that developed instruments are measuring what they are supposed to be measuring." Following this suggestion, we tested content validity, construct validity and reliability (Straub, 1989, p. 150). In order to ensure content validity of our survey instrument we pilot tested our questionnaire (Zikmund, 2003).

\section{Pilot Test of Questionnaire}

Our questionnaire was initially given to a group of colleagues with expertise in survey design who served as a type of expert panel. Based on their feedback, several of the questions on the survey instrument were modified and changed. A second pilot testing was performed with a group of 10 entrepreneurs. Based on this second analysis, additional wording modifications were made to ensure that the original text was clearly interpreted in the target language.

Since, construct validity test contributes to convergent and discriminant validity, if constructs are valid in this sense, one can expect relatively high correlations between measures of constructs that are expected to differ (Straub (1989, p. 150). In our study, construct validity was assessed through exploratory and confirmatory factor analysis. Convergent validity was tested by examination of the factor loading of each construct (item) and measuring factor loading t-value. Cronbach's Alpha was used to reinforce the construct validity of the selected measures, parameter estimation and model validation tests were conducted, and several indices were 
used to assess the fit of the measurement model (Diamantopoulos and Singuaw, 2000; Medsker et al., 1994). In our analysis, we focused on goodness of fit index (GFI), adjusted GFI (AGFI) (whose values from .85 to .90 are considered acceptable (Medsker et al., 1994)), and non-normed fit index (NNFI), whose values should be close to 1 for a good fit of the model (Diamantopoulos and Singuaw, 2000). We also examined the root mean square error of approximation (RMSEA), which should be below .08 for an acceptable fit (Diamantopoulos and Singuaw, 2000). We focused on these measures as they have been widely used in previous studies (Hsu and Sabherwal, 2012; Sharabati et al., 2010; Shih et al., 2010). We developed our measurement process using the statistical software " $R$ " to develop descriptive statistics, exploratory factor analysis and Cronbach's Alpha analysis, where confirmatory factor analysis and SEM analysis were developed using "LISREL 8.80."

\section{RESULTS}

\section{Preliminary measures}

Our model used a maximum likelihood estimation method. We tested observed variables to verify skewedness or kurtosis.
Coefficients of skewedness for the observed variables ranged from -0.40 to 0.90 , and the coefficients of kurtosis ranged from -0.9 to 1.5. The results confirm the validity of the maximum likelihood approach since skewedness indices should be less than 3 and kurtosis less than 8 (Kline, 2005).

For analyzing Innovation Attitude, we used exploratory factor analysis. The factor extrapolation process generates two factors with an eigenvalue greater than 1 . The two factors explain more than $55 \%$ of the overall variance of the twelve items used to measure Innovation Attitude. We found that the two groups were consistent with incremental innovation approach and radical innovation approach. In addition, we conducted a reliability test using Cronbach's Alpha to verify consistency of these latent constructs obtaining values above 0.80 . We also developed a confirmatory factor analysis to confirm that all factor loadings are significant for Incremental and Radical Innovation Group with a minimum $\mathrm{t}$ - value of 13.77 and a minimum r-squared of 0.36. All fit measures indicated a good fit. Table 2 provides the complete list of questions developed and explains the main results obtained.

Table 2. Innovation attitude

Questions: Please indicate the extent to which the following sentences describe your organization's innovation ( 1 not at all to 5 at all)

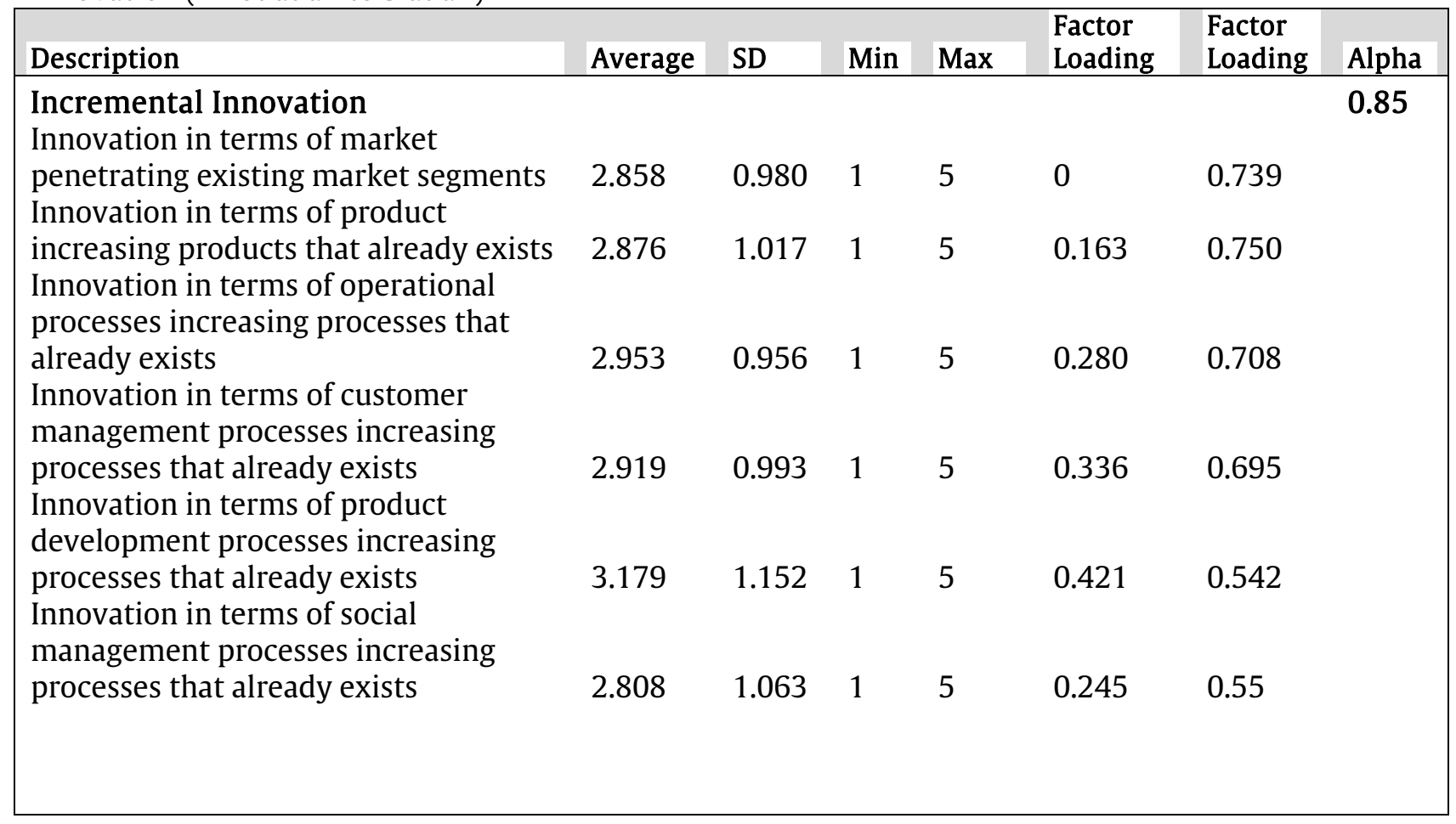


Table 2. Innovation attitude (Continue)

Radical Innovation

Innovation in terms of market

penetrating new markets

Innovation in terms of product

launching new products

$\begin{array}{llllll}3.705 & 1.2 & 1 & 5 & 0.658 & 0.186\end{array}$

Innovation in terms of operational

processes launching new processes

Innovation in terms of customer

management processes launching new

processes

Innovation in terms of product

development management processes

launching new processes

$\begin{array}{llllll}3.578 & 1.237 & 1 & 5 & 0.665 & 0.214\end{array}$

$\begin{array}{llllll}3.702 & 1.138 & 1 & 5 & 0.770 & 0.237\end{array}$

Innovation in terms of social

management processes launching new

processes

$\begin{array}{llllll}3.730 & 1.136 & 1 & 5 & 0.795 & 0.229\end{array}$

$\begin{array}{llllll}3.739 & 1.171 & 1 & 5 & 0.747 & 0.242\end{array}$

Number of observation: $319 ; \mathrm{p}$-value is $0.0000 ; \mathrm{p}<.0001$

On Risk-Taking, we applied an exploratory factor analysis obtaining one factor with eigenvalue higher than 1 . To provide consistency to our analysis we measured Cronbach's Alpha first obtaining values above
0.77. We used confirmatory factor analysis to verify our results. Table 3 provides the complete list of questions developed and explains the main results obtained.

Table 3. Risk Preference

Questions: Please indicate the extent to which the following sentences describe your organization's innovation ( 1 not at all to 5 at all)

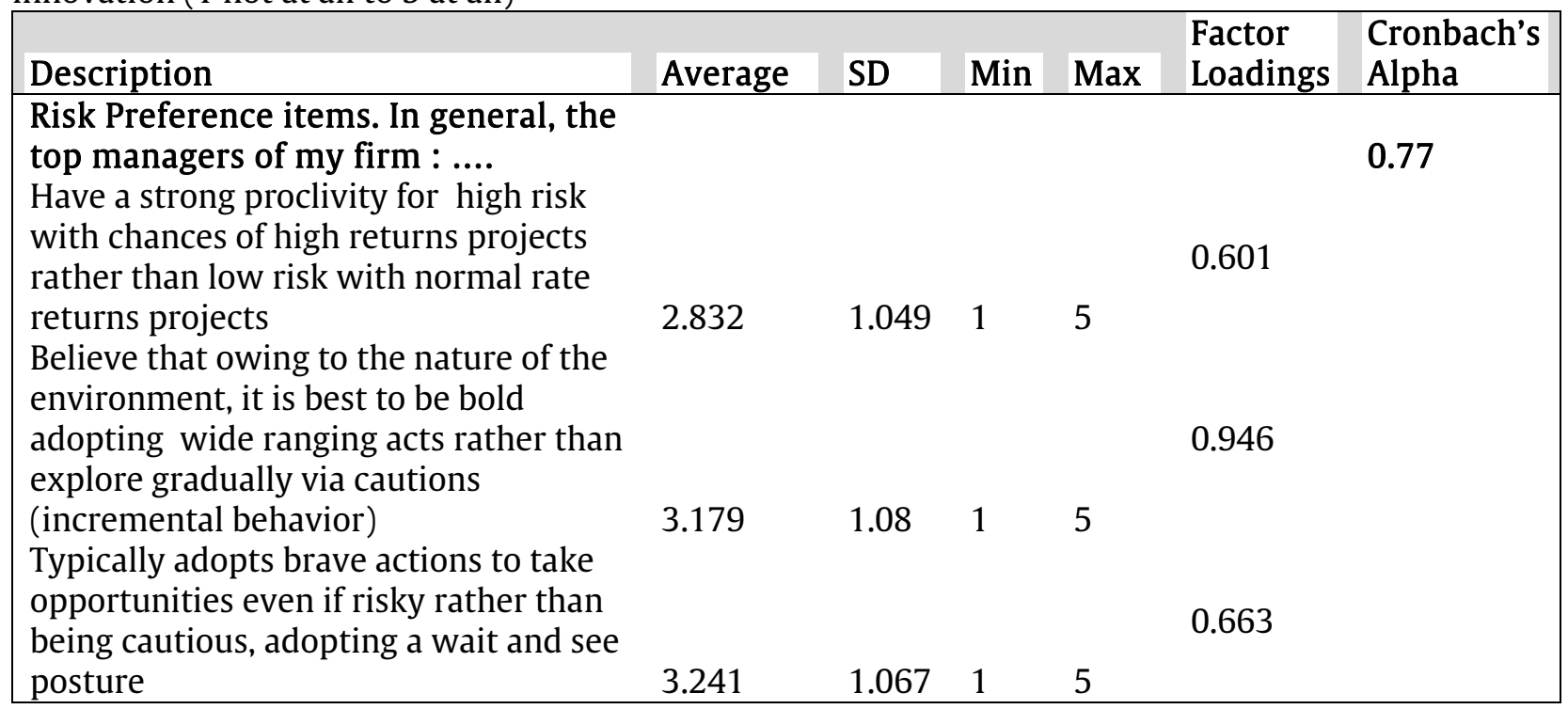

Number of observation: $319 ; \mathrm{p}$-value is $0.0000 ; \mathrm{p}<.0001$

In order to measure Strategic Intent, we carried out an exploratory factor analysis first, obtaining one factor with eigenvalue higher than 1 . To provide consistency to our data we developed a Cronbach's Alpha measure obtaining values above 0.77 . We also carried out a confirmatory factor analysis obtaining for each factor loadings p-value less than 0.01. Table 4 provides the complete list of questions developed and explains the main results obtained. 
Table 4. Strategic Intent

Questions: Please indicate the extent to which the following sentences describe your organization's innovation ( 1 not at all to 5 at all)

\begin{tabular}{|llllllll|}
\hline Description & Average & SD & Min & Max & $\begin{array}{l}\text { Factor } \\
\text { Loadings }\end{array}$ & $\begin{array}{l}\text { Cron- } \\
\text { bach's } \\
\text { Alpha }\end{array}$ \\
\hline Strategic Intent & & & & & & 0.77 \\
Importance of Novelty of products & 0.705 & 1.127 & 1 & 5 & 0.615 & \\
Importance of firm growth & 2.653 & 1.143 & 1 & 5 & 0.783 & \\
Importance of Product performance & 2.947 & 1.177 & 1 & 5 & 0.783 & \\
$\begin{array}{l}\text { Material quality of our products (raw } \\
\text { materials, ...) }\end{array}$ & 2.421 & 1.016 & 1 & 5 & 0.568 \\
$\begin{array}{l}\text { Immaterial quality of our products } \\
\text { (image,...) }\end{array}$ & 2.495 & 0.953 & 1 & 5 & 0.445 \\
\hline
\end{tabular}

Number of observation: $319 ; \mathrm{p}$-value is $0.0000 ; \mathrm{p}<.0001$

To measure export performance, we developed the same process used previously. Exploratory factor analysis was used obtaining only one factor with an eigenvalue higher than 1. We developed then a consistency test obtaining a Cronbach's Alpha of 0.881 .

Table 5 provides the complete list of questions developed and explains the main results obtained.

Table 5. Performance

Questions: Please indicate the extent to which the following sentences describe your organization's innovation ( 1 not at all to 5 at all)

\begin{tabular}{|c|c|c|c|c|c|c|}
\hline Description & Average & SD & Min & Max & $\begin{array}{l}\text { Factor } \\
\text { Loadings }\end{array}$ & $\begin{array}{l}\text { Cronb } \\
\text { ach's } \\
\text { Alpha }\end{array}$ \\
\hline Export Performance & & & & & & 0.881 \\
\hline $\begin{array}{l}\text { Revenues from export are superior to the one } \\
\text { of my competitor }\end{array}$ & 2.858 & 0.829 & 1 & 5 & 0.725 & \\
\hline $\begin{array}{l}\text { Net Operating Income from export sales are } \\
\text { superior to the one of my competitor }\end{array}$ & 2.887 & 0.861 & 1 & 5 & 0.941 & \\
\hline $\begin{array}{l}\text { Net Income from export sales are superior to } \\
\text { the one of my competitor }\end{array}$ & 2.937 & 0.887 & 1 & 5 & 0.873 & \\
\hline
\end{tabular}

Number of observation: 319 ; $\mathrm{p}$-value is $0.0000 ; \mathrm{p}<.0 .001$

\section{Research Questions Test Results}

\section{HO: $R Q 1$ to $R Q 3$}

Although our findings did not support RQ1, we found evidence to support RQ2: Export Performance is directly and positively influenced by Incremental Innovation with a coefficient of $0.35, t$-value of 3.86 , reaching a statistical significance. From this, we rejected our Null Hypothesis (H0) developed for RQ2 recognizing a direct and positive effect of Incremental Innovation on export performance.

Our results also confirmed a direct and positive effect of Radical Innovation on Incremental Innovation, thus rejecting hypothesis 0 developed for RQ3. Radical Innovation positively influences Incremental Innovation with a coefficient of 0.53 and a tvalue of 7.11 and a statistical significance pvalue less than 0.01 .

Our findings further led us to shed new light on the relationship of innovation and export performance. While Anon-Higon and Driffield (2011) found a questionable connection between process innovation and product innovation, our study has given us insight on the quality of innovation. Table 6 shows the parameter estimation and validation results for the SEM. 
Table 6. Model parameters

\begin{tabular}{|c|c|c|c|c|c|}
\hline \multirow{2}{*}{\multicolumn{2}{|c|}{ Research question and model specification }} & \multicolumn{3}{|c|}{ Measures } & \multirow{2}{*}{$\begin{array}{l}\text { Hypotheses } \\
\text { test }\end{array}$} \\
\hline & & \multirow{2}{*}{$\begin{array}{l}\text { Coefficient } \\
-0.11\end{array}$} & \multirow{2}{*}{$\begin{array}{l}\text { t-value } \\
-1.32\end{array}$} & \multirow[t]{2}{*}{ p-value } & \\
\hline RQ1 & $\begin{array}{l}\text { Radical innovation } \rightarrow \text { Export } \\
\text { Performance }\end{array}$ & & & & - \\
\hline RQ2 & $\begin{array}{l}\text { Incremental Innovation } \rightarrow \text { Export } \\
\text { Performance }\end{array}$ & 0.35 & 3.86 & $* * *$ & $\mathrm{H}_{0}$ Rejected \\
\hline RQ2 & $\begin{array}{l}\text { Radical innovation } \rightarrow \text { Incremental } \\
\text { Innovation }\end{array}$ & 0.53 & 7.11 & $* * *$ & $\mathrm{H}_{0}$ Rejected \\
\hline RQ4 & Strategic Intent $\rightarrow$ Export Performance & 0.012 & 0.16 & & - \\
\hline RQ5 & Strategic Intent $\rightarrow$ Radica Innovation & 0.21 & 3.14 & $* * *$ & $\mathrm{H}_{0}$ Rejected \\
\hline RQ6 & $\begin{array}{l}\text { Strategic Intent } \rightarrow \text { Incremental } \\
\text { Innovation }\end{array}$ & 0.23 & 3.73 & $* * *$ & $\mathrm{H}_{0}$ Rejected \\
\hline RQ7 & Risk Preference $\rightarrow$ Export Performance & 0.14 & 2.02 & $* *$ & $\mathrm{H}_{0}$ Rejected \\
\hline RQ8 & Risk Preference $\rightarrow$ Radical Innovation & 0.33 & 4.82 & $* * *$ & $\mathrm{H}_{0}$ Rejected \\
\hline RQ9 & $\begin{array}{l}\text { Risk Preference } \rightarrow \text { Incremental } \\
\text { Innovation }\end{array}$ & 0.049 & 0.78 & & - \\
\hline \multicolumn{2}{|c|}{ Goodness of fit indices } & \multicolumn{4}{|c|}{$\begin{array}{l}\chi 2=552, \text { d.f. }=220, \text { CFI }=0.96, \text { NNFI }=.95, \text { RMSEA }= \\
.069\end{array}$} \\
\hline
\end{tabular}

Interestingly, from our analysis, we were not able to confirm what was found by MinguelaRata et al., 2014 in their study "Cooperation with suppliers, firm size and product innovation"): Radical Innovation does not offer a higher potential competitive advantage than Incremental Innovation. However, it is our hypothesis that due to the financial and economic constraints of SMEs, especially those in our sample population in Italy and Slovenia that were severely impacted by the economic downturn, SMEs are much more prudent and the effectiveness of radical innovation might be thereby reduced. This caution and prudence by SMEs is confirmed in other research by Cohen et al. (2014).

However, notwithstanding these limitations and objections, our results clearly show that radical innovation can be the first step of an innovation path which in the end might lead to an incremental innovation process. In our estimations, these results offer a new understanding on the quality and quantity of the connection between innovation and export performance, offering the basis to introduce a contingency approach.

\section{HO: RQ4 to RQ6}

We did not find a statistically significant relationship between Strategic Intent and export performance. The calculated coefficient is almost 0 and the t-value only 0.16 . Even though this gives no evidence to support RQ4, we did find evidence to support both RQ5 and RQ6, as the coefficient that connects Strategic Intent with Radical Innovation with a value of 0.21 and with a t-value of 3.14 provides a statistical significance p-value less than 0.01 . The coefficient that connects Strategic Intent to Incremental Innovation was 0.23 with a t-value of 3.73 which also was statistical significance. These results confirm prior studies (Acedo and Galan, 2011) of the need to include psychological variables that might condition owner-managers' decision-making responses to understand firms' behavior.

\section{$H O: R Q 7$ to $R Q 9$}

In our analysis of RQ7, we found a direct influence of export performance by risk preference with a coefficient of 0.14 and t-value of 2.02, showing a statistically significant relationship even though the p-value is only less than 0.05. Risk preference has a direct and positive connection also with Radical Innovation with a coefficient of 0.33 and a pvalue of 4.82. This finding supports our RQ8, and thus rejects our connected hypothesis HO. We did not find evidence to connect Risk Preference with incremental innovation and thus we are not able to confirm our hypothesis HA developed for our RQ9. Interestingly, these results provide a better understanding of export performance: Exporting forces entrepreneurs to move to less known markets, 
and this requires a higher level of risk attitude. Similarly, to this, radical innovation requires higher investment compared to incremental innovation and usually presents higher levels of risk. This justifies the connection between risk preference and these variables.

A final test was carried out to assess the validity of the model by measuring goodnessof fit: The higher the model fit, the higher the usability of the model. Among the absolute fit indicators, the GFI value of the model is 0.87 . Root Mean Square Error of Approximation (RMSA) is 0.069, all within an acceptable range. Analyzing incremental fit indicators, the adjusted goodness of fit index (AGFI) was 0.84, normed fit index (NFI) value was 0.93 and incremental fit index (IFI) was 0.96. All the incremental measure reach the standards suggested by the literature and above described. The bottom of Table 6 summarizes the parameter statistics and goodness of fit indexes.

Figure 3 offers a graphical representation of our results. The theoretical model is depicted, and the coefficients and R-squares are highlighted. Significant relationships are depicted with a continuous arrow, while nonsignificant relationships are depicted with a dashed arrow.

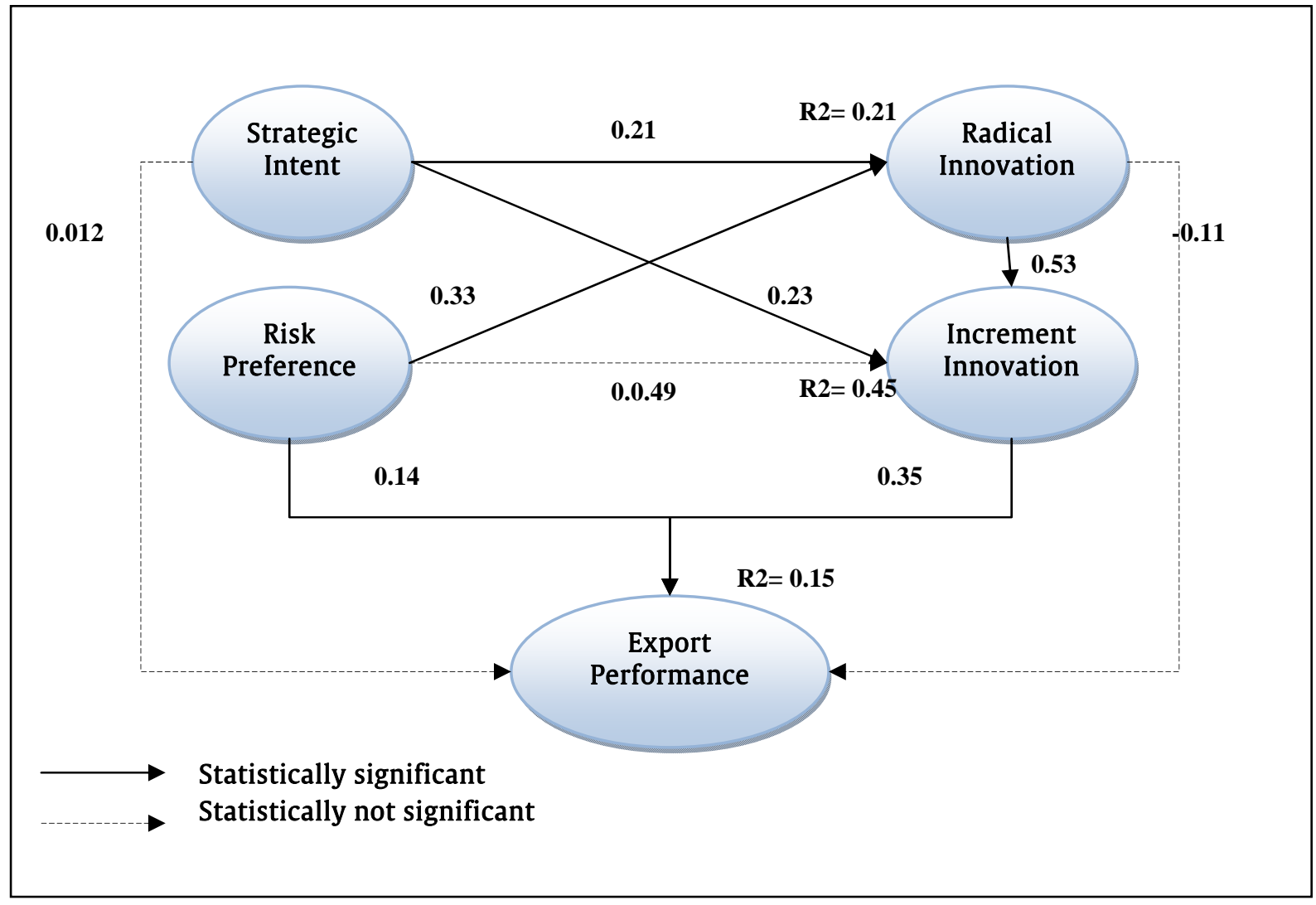

Figure 3: Model parameters 


\section{DISCUSSION AND CONCLUSION}

Although many countries in the west are in a state of political transition, several factors remain constant. First, there remains a growing concern about the world economy and the onset of another economic slowdown and/or recession. Second, regardless of nationalistic overtures and the anti-globalization movement in select countries, nations' economies remain interconnected and global sourcing is intrinsically connected to the production of goods and services worldwide. Third, although SMEs historically conducted their business activities in the region surrounding their firm's location (frequently staying within their national boundaries), the globalized economy, decreasing demands within their local markets, and threats of economic recessions and uncertainly have led many SMEs to go beyond their borders for survival and continued growth. Thus, SMEs in varied countries throughout Europe and beyond, now and in the future, will become both regional and international players. This fact is illustrated in our study of SMEs in Italy and Slovenia countries that are highly represented by SMEs and strained by economic uncertainty in our global world. Moreover, the dominance of SMEs in the neighboring regions of Northern Italy and Slovenia has made them highly competitive, especially through their cross-border connections.

The objective of this study was to assess how SMEs in the two regions undertook or expanded internationalization in the context of the recent global financial crisis which has caused internal demand to struggle and from where export is considered the best way to fight the crisis and ultimately their firm's survival. We approached SMEs operating in Italy and Slovenia, areas where the global financial crisis created a significant impact. The statistical results verify one of our primary research questions: incremental innovation offers a higher potential competitive advantage than radical innovation. We also asked whether risk preference and strategic intent are entrepreneurial variables that affect the export decision-making process in SMEs. Surprisingly, our analysis found that even though both strategic intent and risk preference positively affect innovation, strategic intent is not a determinant of export performance, while preference for risk-taking does have a positive impact on export performance. Cumulatively the results of our analysis are consistent with previous studies, where contingency approach is used to explain internationalization. In addition, our research results lead us to view internationalization theories from a different viewpoint. It is the authors' belief that while internationalization theories of the Uppsalatype have been developed and found adequately represented in times of economic stability and incremental growth, they should be complemented by a contingency approach which may better explain how businesses behave in times of crises and forced globalization. Furthermore, we feel that the results of our study could be useful on a theoretical perspective contributing to the ongoing debate on the topic.

The practical implications of our results provide managers of SMEs insight into several different factors important to decision-making in internationalization:

- First, managers would have to determine which innovation process, radical or incremental, to follow when internationalizing.

- Second, when managers form their internationalization strategy, they must be flexible and willing to accept risk to respond to opportunities that arise, rather than being resistant to spontaneous changes in their strategy.

In regard to generalization of our study findings, we feel the results are limited to the use of a sample derived from only two regions with cultural or country-specific determinants. Also, while traditional theory upholds that firms when internationalizing, implement a "stagedapproach" as shown in the Uppsala Model, our findings indicate that firms must leapfrog, not only to remain competitive, but to gain and regain a competitive advantage. This contingency-driven approach is imperative due to multiple factors ranging from the interconnectedness of our world economy in time of crisis, to the rapid pace in which technology and innovation occurs in our global market.

In future studies, we recommend that researchers use a longitudinal approach (based on data of more than one year) rather than a cross section study in their study of contingency model of internationalization. In addition, retrospective analysis should be conducted on identifying firms (Both SMEs and 
larger firms) that were successful in their export activities during the economic downturn to determine the processes that contributed to their successful internationalization. In addition, our study can support policy-making to support SMEs' internationalization, such as specific activities to foster incremental and continuous innovation to build rewards for risk-taking in cross-border business, and to institutionalize cross-border regional SME collaboration.

In closing, although dramatic changes are occurring in the U.S. and Europe, which may result in more worldwide economic downturns, different trade agreements, and the dissolution of certain trade pacts, innovation, cross-border trade, and our global market place will continue. Thus, it is imperative that we better understand the processes and motivations of SMEs with international trade.

\section{REFERENCES}

Acedo, F.J. \& Galan, J.L. (2011). Export stimuli revisited: The influence of the characteristics of managerial decision makers on international behavior. International Small Business Journal, 29(6), 648-670.

Andersen, O. (1993). On the Internationalization Process of Firms: A Critical Analysis. Journal of International Business Studies, 24(2), 209-231.

Andersen, T.J. \& Nielsen, B.B. (2009). Adaptive strategy making: The effects of emergent and intended strategy modes. European Management Review, 6(2), 94- 106.

Anon Higon, D. \& Driffield, N. (2011). Exporting and innovation performance: Analysis of the annual Small Business Survey in the UK. International Small Business Journal, 29(1), 4-24.

Ahokangas, P. (1998). Internationalization and resources: an analysis of processes in Nordic SMEs. Doctoral Dissertation, Universitas Wasaensis, Vaasa.

Bagchi-Sen, S. \& Kuechler, L. (2000). Strategic and functional orientation of small and medium sized enterprises in professional services: An analysis of public accountancy. The Service Industries Journal, 20(3), 117-146.

Barbosa, S.D., Gerhardt, M.W. \& Kickul, J.R. (2007). The Role of Cognitive Style and
Risk Preference on Entrepreneurial SelfEfficacy and Entrepreneurial Intentions. Journal of Leadership \& Organizational Studies, 13(4), 86-104.

Basile, R. (2001). Export behaviour of Italian manufacturing firms over the nineties: The role of innovation. Research Policy, 30(8), 1185-1201.

Bell, J. (1995), The internationalization of small computer software firms: A further challenge to 'stage' theories. European Journal of Marketing, 29(8), 60-75.

Bell, J., Crick, D. \& Young, S. (2004). Small firm internationalization and business strategy: an exploratory study of 'knowledge-intensive' and 'traditional' manufacturing firms in the UK. International Small Business Journal, 22, 23-56.

Carneiro, J., Rocha, A. Da \& Silva, J.F. Da. (2011). Determinants of Export Performance : a Study of Large Brazilian Manufacturing Firms. Brazilian Administration Review, 8(2), 107-132.

Cassar, G. (2007). Money, money, money? A longitudinal investigation of entrepreneur career reasons, growth preferences and achieved growth. Entrepreneurship \& Regional Development,19(1), 89-107.

Cassiman, B. \& Golovko, E. (2011). Innovation and internationalization through exports. Journal of International Business Studies, 42(1), 56-75.

Cavusgil, S.T. (1980). On the Internationalisation Process of Firms. European Research, 8(6), 273-81.

Charoensukmongkol, P. (2016). Cultural intelligence and export performance of small and medium enterprises in Thailand: Mediating roles of organizational capabilities. International Small Business Journal, 36(1), 105-122.

Choi, Y.R. \& Shepherd, D.A. (2004). Entrepreneurs' Decisions to Exploit Opportunities. Journal of Management, 30(3), 377-395.

Cohen, S., Naoum, V.-C. \& Vlismas, O. (2014). Intellectual capital, strategy and financial crisis from a SMEs perspective. Journal of Intellectual Capital, 15(2), 294-315.

Cowling, M., Liu, W., Ledger, A., \& Zhang, N. (2015). What really happens to small and 
medium-sized enterprises in a global economic recession? UK evidence on sales and job dynamics. International Small Business Journal, 33(5), 488-513.

Dhanaraj, C., \& Beamish, P. W. (2003). A resource-based approach to the study of export performance. Journal of small business management, 41(3), 242-261.

Daszkiewicz, N., \& Wach, K. (2012). Internationalization of SMEs. Context, Models and Implementation. Gdańsk, Poland: Gdańsk University of Technology Publishers.

Danneels, E. (2002). The dynamics of product innovation and firm competences. Strategic Management Journal, 23(12), 1095- 1121

DeClercq, D., Dimov, D. \& Thongpapanl, N. (2015). Structural and relational interdependence and entrepreneurial orientation in small and medium-sized enterprises: The mediating role of internal knowledge sharing. International Small Business Journal, 33(5), 514-536.

Deng, Z., Guo, H., Zhang, W. \& Wang, C. (2014). Innovation and survival of exporters: $A$ contingency perspective. International Business Review, 23(2), 396-406.

Dess, G. and Robinson, R.B. (1984) Measuring Organisational Performance in the Absence of Objective Measures, Strategic Management Journal, 5, 265-73.

Diamantopoulos, A. \& Singuaw, J.A. (2000). Introducing LISREL. Sage, Los Angeles, doi:10.4135/9781849209359.

Dilalla, L.F. (2000). Structural Equation Modelling: Uses and Issues, in Tinsley, H.E.A. and Weiss, D.J. (Eds.) Handbook of Applied Multivariate Statistics and Mathematical Modeling, (pp 439-464), Academic Press, San Diego, CA.

Douglas, E.J. (2013). Reconstructing entrepreneurial intentions to identify predisposition for growth. Journal of Business Venturing, 28(5), 633-651.

Døving, E. \& Gooderham, P.N. (2008). Dynamic capabilities as antecedents of the scope of related diversification: The case of small firm accountancy practices. Strategic Management Journal, 29(8), 841-857.

Dutta, D.K. \& Thornhill, S. (2008). The evolution of growth intentions: Toward a cognitionbased model. Journal of Business
Venturing, 23(3), 307-332.

Elango, B. (2000) An Exploratory Study into the Linkages Between Corporate Resources and the Extent and Form of Internationalization of U.S. Firms, American Business Review, 18 (2), 1226.

Elliott, L. (2011, August 7). Global financial crisis: five key stages 2007-2011. Retrieved from https://www.theguardian.com/business/2 011/aug/07/global-financial-crisis-keystages.

European Commission. (2007). The Flash Eurobarometer, Brussels. Retrieved from http://ec.europa.eu/public_opinion/flash/f 1196_en.pdf.

European Commission. (2014). Enterprise and Industry 2014 SBA Fact Sheet. Retrieved from http://ec.europa.eu/DocsRoom/document s/16121/attachments/20/.../en/.../native.

Eurostat (2015) Your Key to European Statistics. Retrieved Oct 20, 2015, from: http://epp.eurostat.ec.europa.eu/portal/p age/portal/statistics/themes.

Financial Forecast Center (2015) Retrieved Oct 20, 2015, from:

http://www.forecast.org/unemployment. htm.

Gemunden, H.G. (1991). Success Factors of Export Marketing: A Meta-Analytic Critique of the Empirical Studies, in Paliwoda, S.J. (ed.), New Perspectives on International Marketing (pp 33-62), London: Routledge.

Grant, R.M. (1996). Toward a Knowledge-Based Theory of the Firm. Strategic Management Journal, 17, 109-122.

Hamel, G. \& Prahalad, C.K. (1989). Strategic intent. Harvard Business Review, 67(7), 63-76.

Harms R, Reschke C.H., Kraus S., \& Fink M. (2010). Antecedents of innovation and growth: Analyzing the impact of entrepreneurial orientation and goaloriented management. International Journal of Technology Management, 52(1-2), 135-152.

Harris, R. \& Li, Q.C. (2009). Exporting, R \& D and absorptive capacity in UK establishments: Evidence from the 2001 community innovation survey. Oxford Economic 
Papers, 61(1), 74-103.

Henry, L. (2013). Intellectual capital in a recession: Evidence from UK SMEs. Journal of Intellectual Capital, 14(1), 84101.

Hsu, I.-C. \& Sabherwal, R. (2012). Relationship between Intellectual Capital and Knowledge Management: An Empirical Investigation. Decision Sciences, 43(3), 489-524.

Hutchinson, Fleck and Lloyd-Reason, (2009) An investigation into the initial barriers to internationalization: Evidence from small UK retailers. Journal of Small Business and Enterprise Development, Vol. 16(4), pp. 544 - 568.

Iacobucci, D. \& Spigarelli, F. (2010). Internationalization in Italian Medium Sized Firms: Does Stage Theory Explain the Observed Patterns. In Internationalization, Technological Change and the Theory of the Firm. Editors Nicola De Liso and Riccardo Leoncini. London: Routledge.

Ibeh, K., Johnson, J.E., Dimitratos, P. \& Slow, J. (2004). Micromultinationals: Some Preliminary Evidence on an Emergent 'Star' of the International Entrepreneurship Field. Journal of International Entrepreneurship, 2(4), 289-303.

Johanson, J. \& Vahlne, J.-E. (1975). The internationalization process of the firmFour Swedish case studies. Journal of Management Studies, 12(3), 305-323.

Johanson, J. \& Vahlne, J.-E. (1992). Management of Foreign Management Entry. Scandinavian International Business Review, 1(3), 9-27.

Kraus S, Rigtering JP, Coen JP, et al. (2012). Entrepreneurial orientation and the business performance of SMEs: A quantitative study from the Netherlands. Review of Managerial Science, 6(2), 161182.

Kline, R.B. (2005). Principles and practice of structural equation modeling, Second Ed. The Guilford Press, New York.

Lefebvre, É., Lefebvre, L.A. \& Bourgault, M. (1998). R\&D-Related Capabilities as Determinants of Export Performance. Small Business Economics, 10(4), 365377.
Leonidou, L.C. \& Katsikeas, C.S. (1996). The Export Development Process: An Integrative Review of Empirical Models. Journal of International Business Studies, 27, 517-551.

Love, J.H., Roper, S. \& Du, J. (2009). Innovation, ownership and profitability. International Journal of Industrial Organization, 27(3), 424-434.

McDougall, P.P. and Oviatt, B.M. (1996) New Venture Internationalization, Strategic Change, and Performance: A Follow-up Study. Journal of Business Venturing, II, 23-40.

Masum, M., \& Fernandez, A. (2008). Internationalization Process of SMEs: Strategies and Methods. Master Thesis, Mälardalen University, School of Sustainable Development of Society and Technology, Västerås, Sweden.

Medsker, G.J., Williams, L.J. \& Holahan, P.J. (1994). A review of current practices for evaluating causal models in organizational behavior and human resources management research. Journal of Management, 20(2): 439-464.

Minguela-Rata, B., Fernández-Menéndez, J. \& Fossas-Olalla, M. (2014). Cooperation with suppliers, firm size and product innovation. Industrial Management \& Data Systems, 114(3), 438-455.

Moini, H. \& Moini, A.H. (1995). An Inquiry Into Successful Exporting: An Empirical Investigation Using A Three-Stage Model. Journal of Small Business Management, 33(3), 9-25.

Morgan, N.A., Kaleka, A. \& Katsikeas, C.S. (2004). Antecedents of Export Venture Performance: A Theoretical Model and Empirical Assessment. Journal of Marketing 68, 90-108.

Nakos, G., Brouthers, K.D. and Brouthers, L.E. (I 998). The Impact of Firm and Managerial

Characteristics on Small and Medium-Sized Greek Firms' Export Performance. Journal of Global Marketing, 11 (4), 23-47.

Nguyen, A.N., Quang Pham, N., Nguyen, C.D. \& Nguyen, N.D. (2008). Innovation and exports in Vietnam's SME sector. The European Journal of Development Research, 20(2), 262-280.

Nonaka, I. \& Takeuchi, H. (1995). The Knowledge-Creating Company. How 
Japanese companies create the dynamic of innovation, Oxford University Press, Oxford.

O'Cass, A., \& Weerawardena, J. (2009). Examining the role of international entrepreneurship, innovation and international market performance in SME internationalization. European Journal of Marketing, 43(11/12), 1325-1348.

OEC (Observatory of Economic Complexity, (2016, July 30). Italy. Retrieved from http://atlas.media.mit.edu/en/profile/cou ntry/ita/.

OECD (Organization for Economic Co-operation and Development, 2009). OECD Economic Surveys: Slovenia 2009, OECD, Paris.

Paci, R., \& Usai, S. (2000). Technological enclaves and industrial districts: an analysis of the regional distribution of innovative activity in Europe. Regional studies, 34(2), 97-114.

Papadopoulos, N. \& Martín Martín, O. (2010). Toward a model of the relationship between internationalization and export performance. International Business Review, 19(4), 388-406.

Pla-Barber, J. \& Alegre, J. (2007). Analysing the Link between Export Intensity, Innovation and Firm Size in a Science-based Industry. International Business Review 16(3), 275-293.

Reeb, D., Sakakibara, M., \& Mahwood, I.P. (2012). From the Editors: Endogeneity in international business research. Journal of International Business Studies, 43(3), 211218.

Reynolds, P.D. (1997). New and Small Firms in Expanding Markets. Small Business Economics, 9(1), 79-84.

Robb, D.J., Xie, B. \& Arthanari, T. (2008). Supply chain and operations practice and performance in Chinese furniture manufacturing. International Journal of Production, Economics 112(2), 683-699.

Ruzzier, M., Antončič, B., \& Konečnik, M. (2006). The resource-based approach to the internationalisation of SMEs: Differences in resource bundles between internationalised and noninternationalised companies. Zagreb International Review of Economics and Business, 9 (2), 95-116.

Ruzzier, M., Hisrich, R. D., \& Antoncic, B. (2006).
SME internationalization research: past, present, and future. Journal of small business and enterprise development 13(4), 476-497.

Shamsuddoha, a. K., Ali, M.Y. \& Ndubisi, N.O. (2009). Impact of government export assistance on internationalization of SMEs from developing nations. Journal of Enterprise Information Management, 22(4), 408-422.

Sharabati, A.A., Jawad, S.N. \& Bontis, N. (2010). Intellectual capital and business performance in the pharmaceutical sector of Jordan. Management Decision, 48(1): 105-131.

Shih, K.-H., Chang, C.-J. \& Lin, B. (2010). Assessing knowledge creation and intellectual capital in banking industry. Journal of Intellectual Capital, 11(1), 7489.

Shrader, R.C. (2001). Collaboration and Performance in Foreign Markets: The Case of Young High-Technology Manufacturing Firms. Academy of Management Journal, 44 ( 1), 45-60.

Slovenia Times (2015, December 01). Slovenia at Bottom of EU Rankings in Inward FDI. Retrieved from http://www.sloveniatimes.com/sloveniaat-bottom-of-eu-rankings-in-inward-fdi

Spanos, Yiannis E. and Lioukas, Spyros (2001). An Examination into the Causal Logic of Rent.

Generation: Contrasting Porter's Competitive Strategy Framework and the ResourceBased Perspective. Strategic Management Journal, (22), 907-934.

St-Pierre, J. \& Audet, J. (2011). Intangible assets and performance: Analysis on manufacturing SMEs. Journal of Intellectual Capital, 12(2), 202-223.

Straub, D.W. (1989). Validating instruments in MIS research. MIS Quarterly: Management Information Systems, 13(2), 147-165.

Svetlicic, M. (2004). Outward foreign direct investment by enterprises from Slovenia. Transnational Corporation 16(1), 55-87.

UNCTAD (2004), World Investment Report, 2004: The shift toward Services. United Nations, New York and Geneva,

Wakelin, K. (1998). Innovation and export 
behaviour at the firm level. Research Policy, 26(7-8), 829-841.

Westland, C.J. (2012). Modern path analysis and structural equation models. CreateSpace Independent Publishing Platform, London.

Wolff, J.A. \& Pett, T.L. (2000). Internationalization of Small Firms: An Examination of Export Competitive, Patterns, Firm Size and Export Performance. Journal of small Business Management, 38(4), 34-47.

Wright, M., Westhead, P., \& Ucbasaran, D. (2007). Internationalization of small and medium-sized enterprises (SMEs) and international entrepreneurship: A critique and policy implications. Regional Studies, 41(7), 1013-1030.

Yi, J., Wang, C. \& Kafouros, M. (2013). The effects of innovative capabilities on exporting: Do institutional forces matter? International Business Review, 22(2), 392-406.

Zikmund, W.G. (2003). Business Research Methods. Thomson/South-Western, Mason, USA.

\section{ABOUT THE AUTHORS}

Arthur Rubens, email: arubens@fgcu.edu

Dr. Maurizio Massaro has been an assistant professor at Udine University since 2008. Before joining academia, he was founder and CEO of multiple consultancy firms. He has also served as a research center Vice President in the field of metal analysis. He has been a visiting Professor at Florida Gulf Coast University and Leicester University. He enjoys several contacts and research partnerships with universities in the USA, continental Europe, UK and Australia. His research interests include knowledge management, intellectual capital, and sustainability in international business, and research methods.

Dr. Arthur Rubens is currently a Professor of Management at Florida Gulf Coast University, Lutgert College of Business. He has over 25 years of experience as an educator, administrator, and consultant, and has taught students all over the world. His research interests are in strategy, international business, leadership, ethics, economic development and sustainability.

Dr. Roland Bardy is an Executive Professor at Florida Gulf Coast University's Lutgert College of Business, a retired executive from BASF, and Principal with BardyConsult in Mannheim, Germany. He has over 30 years' experience working with multinationals, and since his retirement in 1999 has lectured and consulted worldwide. His research interests are in leadership, ethics, and sustainability.

Dr. Carlo Bagnoli is Associate Professor of Business Policy and Strategy at the Department of Management, Ca' Foscari University of Venice. He received a Ph.D. in Business Economics at Ca' Foscari University of Venice. He was visiting research fellow at the University of Florida. He is Scientific Director of the Innovarea Project funded by the Regional Italian Government. His research interests include knowledge management, competitive strategy, business model innovation. Carlo's research work has been published in various outlets, including the Journal of Business Economics and Management, Industrial Management \& Data System, Journal of Management and Governance and Journal of Intellectual Capital. 